Original Article

\title{
Phenolic substances and cyanogenesis in galled and non-galled tissue of the fern species Microgramma vacciniifolia
}

\author{
Substâncias fenólicas e cianogênese em tecidos galhados e não galhados da \\ samambaia Microgramma vacciniifolia
}

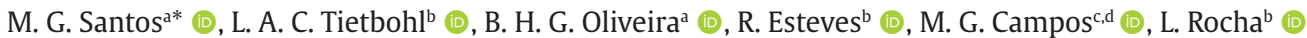 \\ a Universidade do Estado do Rio de Janeiro, Faculdade de Formação de Professores, Laboratório de Biodiversidade, São Gonçalo, RJ, Brasil

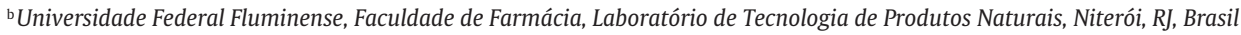 \\ ' Universidade de Coimbra, Faculdade de Farmácia, Observatório de Interações Planta-Medicamento, Pólo das Ciências da Saúde, Azinhaga de Santa \\ Comba, Coimbra, Portugal \\ 'Universidade de Coimbra, Centro de Química de Coimbra - CQC, Coimbra, Portugal
}

\begin{abstract}
Galls, neo-formed plant structures that can occur in different organs, are generated by species-specific interaction with an inducing organism. Inducers manipulate the metabolism of its host. Microgramma vacciniifolia (Langsd. \& Fisch.) Copel. is a Neotropical epiphytic fern that hosted two stem galls, one induced by a midge species (Diptera) and other by a micromoth species (Lepidoptera). The aim of this study was to evaluate the impact of these two gall-inducing insects on the biochemistry of phenolic acids and the cyanogenesis in galls, stems and leaves of M. vacciniifolia. High performance liquid chromatography (HPLC) indicated a total of 14 phenol derivatives, including caffeic and coumaric acid. Principal Coordinates Analysis (PCOA) of the phenolic substances indicated three groups consisting (1) non-galled stems and micromoth-induced galls; (2) midge-induced galls; (3) midgeinduced galls with parasitoids. Regarding the frequency of cyanogenesis assessed by the picrate paper test, the chi-squared test showed significant difference between fertile leaves (8.3\%), sterile leaves (27.7\%), non-galled stems ( $0 \%$ ) and galls. Among galls, only the midge-induced galls analyzed were cyanogenic (15\%). Our results indicated that the different gall-inducers (midge and micromoth) promote species-specific alterations to the phenolic substance composition of the host fern.
\end{abstract}

Keywords: Cecidomyiidae, chemical ecology, fern-insect interactions, micromoth, midge.

\section{Resumo}

Galhas são estruturas vegetais neo-formadas que ocorrem em diferentes órgãos. Elas são geradas por uma interação espécie-específica com um organismo indutor. Os indutores manipulam o metabolismo do hospedeiro. Microgramma vacciniifolia (Langsd. \& Fisch.) Copel. é uma samambaia epífita neotropical que hospeda duas galhas caulinares, uma induzida por uma espécie de mosquito (Diptera) e outra por uma micromariposa (Lepidoptera). O objetivo deste estudo foi avaliar o impacto desses dois insetos indutores de galhas na bioquímica dos ácidos fenólicos e da cianogênese em galhas, caules e folhas de M. vacciniifolia. Em análise de cromatografia líquida de alta eficiência (CLAE) foi possível indicar a presença de um total de 14 derivados fenólicos, incluindo ácido cafeico e ácido cumárico. Análise das Coordenadas Principais (ACoP) indicou três grupos (1) caules não galhados e galhas induzidas pela micromariposa; (2) galhas induzidas pelo mosquito; (3) galhas induzidas pelo mosquito com parasitoides. Em relação a frequência da cianogênese analisada com o teste do papel picrato, o teste do qui-quadrado apresentou diferença significativa entre as folhas férteis (8,3\%), folhas estéreis (27,7\%), caules não galhados (0\%) e galhas. Entre as galhas, somente aquelas induzidas pelo mosquito foram cianogênicas (15\%). Os resultados encontrados indicam, ao menos para as substâncias fenólicas, que os insetos indutores de galha (mosquito e micromariposa) promovem alterações espécie-específica na composição química da samambaia hospedeira.

Palavras-chave: Cecidomyiidae, ecologia química, interações samambaias-insetos, micromariposa, mosquito.

\section{Introduction}

Galls, neo-formed plant structures that can occur in different organs, are generated by species-specific interaction with an inducing organism (Mani, 1964;
Isaias et al., 2014). Gall morphology can be considered an extended phenotype of the galler (Nyman and JulkunenTitto, 2000). Inducers establish a parasitic relationship with

*e-mail: marceloguerrasantos@gmail.com

Received: April 05, 2020 - Accepted: November 10, 2020 
the host plant and manipulate its metabolism, quantitatively and qualitatively regulating the production of substances to create better food and shelter (Mani, 1964; Nyman and Julkunen-Titto, 2000; Raman, 2007; Guiguet et al., 2016). Phenolic substances, tannins, flavonoids and alkaloids accumulate mainly in the gall outer cortex, as a chemical defense or protection against UV radiation, while sugars and proteins are accumulated in gall tissues around the larval chamber (Isaias et al, 2014).

Santos et al. (2019) report galls on 93 host species, belonging to 41 genera of ferns and lycophytes. In Brazil, galls have been recorded on 21 fern species (Santos and Maia, 2018; Farias et al., 2020; Lehn et al., 2020). Galls have been registered in four Microgramma C. Presl (Polypodiaceae) species, M. squamulosa (Kaulf.) de la Sota, M. vacciniifolia (Langsd. \& Fisch.) Copel., M. percussa (Cav.) de la Sota (Santos et al., 2019) and M. mortoniana de la Sota (Lehn et al., 2020)

Microgramma vacciniifolia is a Neotropical epiphytic fern. Two different galls, one ovoid and the other ellipsoid, have been recorded on the stems of this species. The ovoid gall is induced by a midge known as Primadiplosis microgrammae (Cecidomyiidae - Diptera) (Maia and Santos, 2011), which is attacked by two parasitoid wasps: Torymidae and Tetrastichinae (Eulophidae). The ellipsoid gall is induced by the micromoth species Tortrimosaica polypodivora (Lepidoptera: Tortricidae) (Brown et al., 2004), attacked by the parasitoid wasp Cheloninae (Braconidae) (Maia and Santos, 2015).

One form of direct or indirect defense or resistance against herbivores in plants is the production of secondary metabolites (Boege and Marquis, 2005). Among plant chemical defenses, cyanogenic glycosides (CNglcs) are recognized as a direct, constitutive plant defensive trait (Kautz et al., 2014). When plant tissues are injured by herbivores, CNglcs (stored in the vacuoles) come into contact with $\beta$-glucosidase and $\alpha$-hydroxynitrile lyases which hydrolyze the $\mathrm{CNglcs}$ and release hydrogen cyanide $(\mathrm{HCN})$ in a process called cyanogenesis (Vetter, 2000; Zagrobelny et al., 2004; Oliveros-Bastidas and AlonsoAmelot, 2010), which can be polymorphic in a same cyanogenic plant population (Hegnauer, 1977). HCN is extremely toxic to various organisms, inhibiting, for example, oxygen reduction in cytochromes present in the respiratory electron transport chain (Francisco and Pinotti 2000). However, Zagrobelny et al. (2004) reported that cyanogenic glycosides can act as both feeding deterrents and phagostimulants for specialist herbivores that eat plants containing CNglcs.

Similarly, phenolic substances also play a role in plant defense by repelling herbivores or affecting their digestive systems via toxic and ovicidal substances, as well as components that affect insect photosensitivity (Harborne et al., 1999; Mello and Silva-Filho, 2002; Zagrobelny et al., 2004). Phenolic acids such as p-coumaric acid and caffeic acid are frequently found in ferns and other plants (Bohm and Tryon, 1967; Summers and Felton, 1994). The toxicological effect of caffeic and chlorogenic acid against insect herbivores is due primarily to their ability to act as prooxidants, inducing oxidative stress in insect herbivores (Summers and Felton, 1994).
Some studies focus on the chemical strategies used by ferns against herbivores, such as the production of phenolic and cyanogenic substances. Balick et al. (1978) reported condensed tannins in all 26 fern species on which arthropod damage was recorded, and only $3 \%$ of 100 species tested positive for cyanogenesis. According to the authors, it is unlikely that they play a significant role as defensive substances in the ferns examined. However, Cooper-Driver and Swain (1976) suggest that cyanogenic polymorphism in bracken fern (Pteridium aquilinum (L.) Kuhn) has a positive role in determining the degree of herbivore predation. The cyanogenic leaves of this species suffered less damage from chewing herbivores than acyanogenic leaves (CooperDriver and Swain, 1976; Schreiner et al., 1984). The defense syndrome of some tropical ferns combines low nutritional quality, high phenol concentrations, and many trichomes (Farias et al., 2019).

Research on chemical alterations in galls on ferns and lycophytes remains scarce. Patra et al. (2009) evaluated the biochemical changes during gall development in Selaginella species. These authors found that mature galled tissue had a higher sugar and total phenol content than non-galled tissue at the same stage.

In angiosperm-insect systems authors have found a slight increase in some phenolic substances in galled tissue, while others absent in non-galled tissue were detect in galls and, that qualitative and quantitative changes in the gall chemical profile depend on the inducing insect (Nyman and Julkunen-Titto, 2000). These results suggest that galling insects control phenolic biosynthesis in their hosts (Hartley, 1998; Nyman and Julkunen-Titto, 2000). Research on cyanogenesis in galled and non-galled tissues is still scarce.

Santos et al. (2005) studied cyanogenesis in 19 species of ferns and lycophytes over a one-year period, in a rocky outcrop in southeastern Brazil. Among the species analyzed, Microgramma vacciniifolia was found to be cyanogenic throughout the study period, with the following cyanogenesis frequencies: stem (10\%), fertile leaves (40\%) and sterile leaves (47\%). The effects of herbivorous stress were not evaluated. Peres et al. (2009) isolated and identified in M. vacciniifolia phenolic substances and ethyl esters of carboxylic acids. However, none of the studies analyzed variations in the chemical profile between the galled and non-galled tissue of M. vacciniifolia.

The hypotheses to be tested are (1) the gallers of $M$. vacciniifolia stem promote a qualitative alteration of phenolic substances in their galled tissues, and (2) The frequency of cyanogenesis in $M$. vacciniifolia stems and galls is lower than that of leaves.

Thus, the aim of this study was to evaluate the impact of two gall-inducing insects on the biochemistry of phenolic acids of the host fern, and the prospection of cyanogenesis in galled and non-galled tissue of M. vacciniifolia.

\section{Materials and Methods}

Microgramma vacciniifolia samples were collected in a Myrtaceae "thicket" community ( $22^{\circ} 57^{\prime} 39.6^{\prime} \mathrm{S}$ $\left.42^{\circ} 51^{\prime} 43.0^{\prime \prime} \mathrm{W}\right)$, a dense shrubby vegetation growing on 
the beach ridges from the restinga (sandy coastal plains) vegetation of the Maricá Environmental Protection Area in Rio de Janeiro state, Brazil. The voucher specimens (M.G. Santos 2250) were deposited in the FFP-UERJ Herbarium (RFFP).

\subsection{Profile of the phenolic substances}

The samples were collected in one day of March 2015 (rainy season) from seven different individuals of M. vacciniifolia and mixed into one composite sample, placed in plastic bags and taken to the Laboratório de Tecnologia de Produtos Naturais of the Universidade Federal Fluminense. The extraction was carried in the same day and the profile of the substances was evaluated one week later. We analyzed galls induced by midge (MIG), galls induced by micromoth (MMIG), non-galled stems near of the midge induced galls (SNM) and non-galled stems near of the micromoth induced gall (SNMM).

Methanolic extracts were obtained at $60{ }^{\circ} \mathrm{C}$ under magnetic stirring, for five minutes (min.), using a $1: 10$ solution ( $1 \mathrm{~g}$ of fresh plant material in $10 \mathrm{~mL}$ of methanol). The chromatographic profile of the substances was evaluated by high performance liquid chromatography (HPLC) (Shimadzu LC-20A), using the following analytical conditions: a Phenomenex ${ }^{\circledR}$ Synergi Hydro RP18 (250 mm x 4.6 mm i.d. particle size $4 \mu \mathrm{m})$ column, Jasco ${ }^{\circledR}$ chromatograph, and flow rate of $1.0 \mathrm{~mL} / \mathrm{min}$. Mobile phase: $\mathrm{MeOH}+0.1 \% \mathrm{TFA} 0.1 \%$ (B) and $\mathrm{H}_{2} \mathrm{O}+0.1 \%$ TFA (A). Gradient elution was $0-20 \%$ B (20 $\mathrm{min}), 20 \%$ B (isocratic, $2 \mathrm{~min}$ ), 20-50\% B (38 min), and $50-100 \% \mathrm{~B}$ ( $5 \mathrm{~min}$ ). The analysis lasted $65 \mathrm{~min}$ and the wavelength of the diode array detector (DAD) was fixed at $285 \mathrm{~nm}$. The retention times and peaks were used as indicative to differentiate between substances. Peak purity measurement was used, indicating that each peak corresponds to only one substance. The UV-spectra of the separated substances were analyzed in line with Campos and Markham (2007).

\subsection{Cyanogenesis}

The samples were collected on one day in June and one in August 2011 (dry season), and one day in March 2012 (rainy season), placed in plastic bags and taken to the Laboratório de Biodiversidade of the Faculdade de Formação de Professores (FFP), Universidade do Estado do Rio de Janeiro (UERJ). The analysis was conducted on the same day. Midge $(\mathrm{N}=20)$ and micromoth-induced galls $(\mathrm{N}=28)$ as well as non-galled stems near the former $(\mathrm{N}=20)$ and the latter $(\mathrm{N}=28)$ were used, in addition to sterile $(\mathrm{N}=47)$ and fertile $(\mathrm{N}=25)$ leaves. Samples were tested in isolation. Cyanogenesis was detected using the picrate paper test prepared by rectangular pieces of filter paper dripped with a saturated aqueous picric acid solution neutralized with $\mathrm{NaHCO}_{3}$. The botanical sample was ground in a test tube and 3 drops of chloroform was added. Next, the picrate paper was putting inside of test tube, which was sealed with a stopper. A color change from yellow to reddish indicates a positive result for cyanogenesis (Harborne, 1984; Santos et al., 2005).

\subsection{Statistical analyses}

Principal Coordinates Analysis (PCoA) was performed based on presence and absence of the phenolic substances in galled and non-galled stems of M. vacciniifolia, using the Sørensen similarity index. The chi-squared test $\left(\mathrm{X}^{2}\right)$ was conducted to demonstrate the significant difference of cyanogenesis in different tissues of M. vacciniifolia. PAST (PAleontological STatistics) software version 3.10 was used for data analysis.

\section{Results}

Based on the retention times, a total of 14 phenolic substances were detected. Of these, 12 were found in nongalled stems (SNMM and SNM), 10 in midge-induced galls with parasitoids (MIGP), nine in micromoth-induced galls (MMIG), and six in midge-induced galls (MIG) (Table 1; Figures 1 and 2).

Wavelength analysis indicated that substances 1, 3 6,8 and 9 are caffeic acid derivatives and substance 7 is more likely a coumaric acid derivative (Figures 1 and 2).

Figure 3 shows Principal Coordinates Analysis of the phenolic substances in galled and non-galled stems of M. vacciniifolia (Table 1 ). Axis 1 explains $55.8 \%$ and the axis $235.19 \%$ of the variance (total=90.99\%). The axis 1 separates SNMM, SNM, MMIG and MIGP from MIG, the last forming an isolated group. Axis 2 separates SNMM, SNM and MMIG from MIGP (Figure 3). In MIGP two new substances (A and B) are present in the chemical profile, and substance 12 was only detected in non-galled stems (SNM and SNMM). Substances 4, 5, 7, 8 and 11 were detected in all the samples (Table 1).

With respect to cyanogenesis, the frequency differed significantly $\left(X^{2}=27.02, D F=7, P=0.0003\right)$ between galls, non-galled stems, fertile and sterile leaves. None of the micromoth-induced galls or adjacent non-galled stems exhibited cyanogenesis. However, $15 \%$ of the midgeinduced galls analyzed were cyanogenic. The sterile leaves were cyanogenic in $27.7 \%$, and fertile leaves in $8.3 \%$ of the samples (Table 2).

\section{Discussion}

Analysis of the chemical profile of phenolic substances in galled and non-galled stems of the fern species M. vacciniifolia indicated changes in the relative amounts of these substances and in the induction of new substances in galled tissue. Nyman and Julkunen-Titto (2000) also observed a difference between the chemical profiles of galled and non-galled plant tissue in the sawfly-willow system. The authors found a slight increase in some phenolic substances in galls, while others absent in non-galled tissue were detected in galls. It has been suggested that plants raise the production of phenolic substances in tissue where galling insects have laid their eggs (Isaias et al., 2014) due a response to oxidative stress promoted by the insects (Soares et al., 2000).

In Microgramma vacciniifolia, the chemical composition of non-galled stems (SNM and SNMM) was similar to that 
Table 1. Retention time (RT), signal area (SA) for compounds detected in the chromatograms of methanolic Microgramma vacciniifolia extracts. SNM (stem non-galled by midge), MIG (midge-induced galls), MIGP (midge-induced galls attacked by parasitoids), SNMM (stem non-galled by micromoth), MMIG (micromoth-induced galls), mAU (milli-Absorbance Units), min. (minutes), (-) not detected.

\begin{tabular}{|c|c|c|c|c|c|c|c|c|c|c|}
\hline \multirow{2}{*}{ 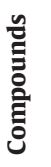 } & \multicolumn{2}{|c|}{ SNM } & \multicolumn{2}{|c|}{ MIG } & \multicolumn{2}{|c|}{ MIGP } & \multicolumn{2}{|c|}{ SNMM } & \multicolumn{2}{|c|}{ MMIG } \\
\hline & $\underset{(\min .)}{\mathbf{R T}}$ & $\begin{array}{c}\text { SA } \\
(\mathbf{m A U})\end{array}$ & $\underset{(\min .)}{\text { RT }}$ & $\begin{array}{c}\mathrm{SA} \\
(\mathbf{m A U})\end{array}$ & $\underset{(\mathbf{m i n} .)}{\mathbf{R T}}$ & $\underset{(\mathrm{mAU})}{\mathrm{SA}}$ & $\begin{array}{c}\text { RT } \\
\text { (min.) }\end{array}$ & $\underset{(\mathbf{m A U})}{\mathrm{SA}}$ & $\underset{(\text { min. })}{\mathbf{R T}}$ & $\begin{array}{c}\text { SA } \\
(\mathbf{m A U})\end{array}$ \\
\hline A & - & - & - & - & 9.560 & 211101 & - & - & - & - \\
\hline B & - & - & - & - & 11.372 & 60028 & - & - & - & - \\
\hline 1 & 25.519 & 70342 & - & - & 25.522 & 92303 & 25.542 & 41205 & 25.516 & 15704 \\
\hline 2 & 29.058 & 43576 & - & - & 29.073 & 37250 & 29.053 & 37483 & 29.044 & 54020 \\
\hline 3 & 29.947 & 29354 & - & - & 29.960 & 54360 & 29.950 & 25281 & - & - \\
\hline 4 & 34.354 & 159806 & 34.345 & 215401 & 34.352 & 816033 & 34.345 & 91518 & 34.338 & 72466 \\
\hline 5 & 35.763 & 75375 & 35.745 & 19447 & 35.751 & 116660 & 35.751 & 37081 & 35.754 & 20611 \\
\hline 6 & 40.702 & 49040 & - & - & - & - & 40.702 & 49040 & 40.704 & 20637 \\
\hline 7 & 41.176 & 144946 & 41.126 & 483588 & 41.140 & 633298 & 41.184 & 199151 & 41.169 & 118254 \\
\hline 8 & 43.566 & 73625 & 43.534 & 574443 & 43.532 & 540211 & 43.537 & 241597 & 43.532 & 179910 \\
\hline 9 & 47.196 & 91550 & - & - & - & - & 47.194 & 59084 & 47.180 & 37023 \\
\hline 10 & 47.709 & 38641 & 47.196 & 21052 & - & - & 47.705 & 24772 & - & - \\
\hline 11 & 50.635 & 21766 & 50.328 & 208457 & 50.319 & 68714 & 50.622 & 18536 & 50.323 & 62517 \\
\hline 12 & 52.496 & 34240 & - & - & - & - & 52.490 & 50264 & - & - \\
\hline
\end{tabular}
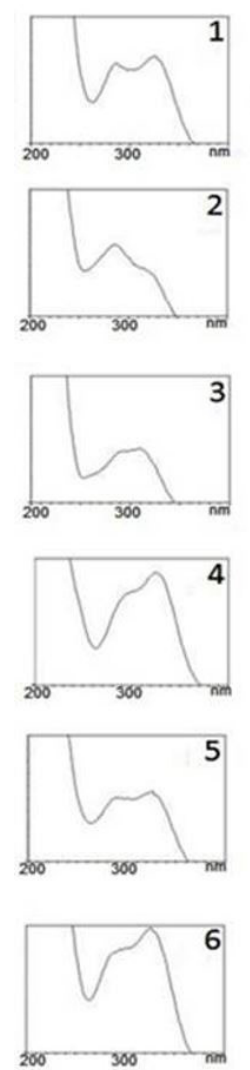
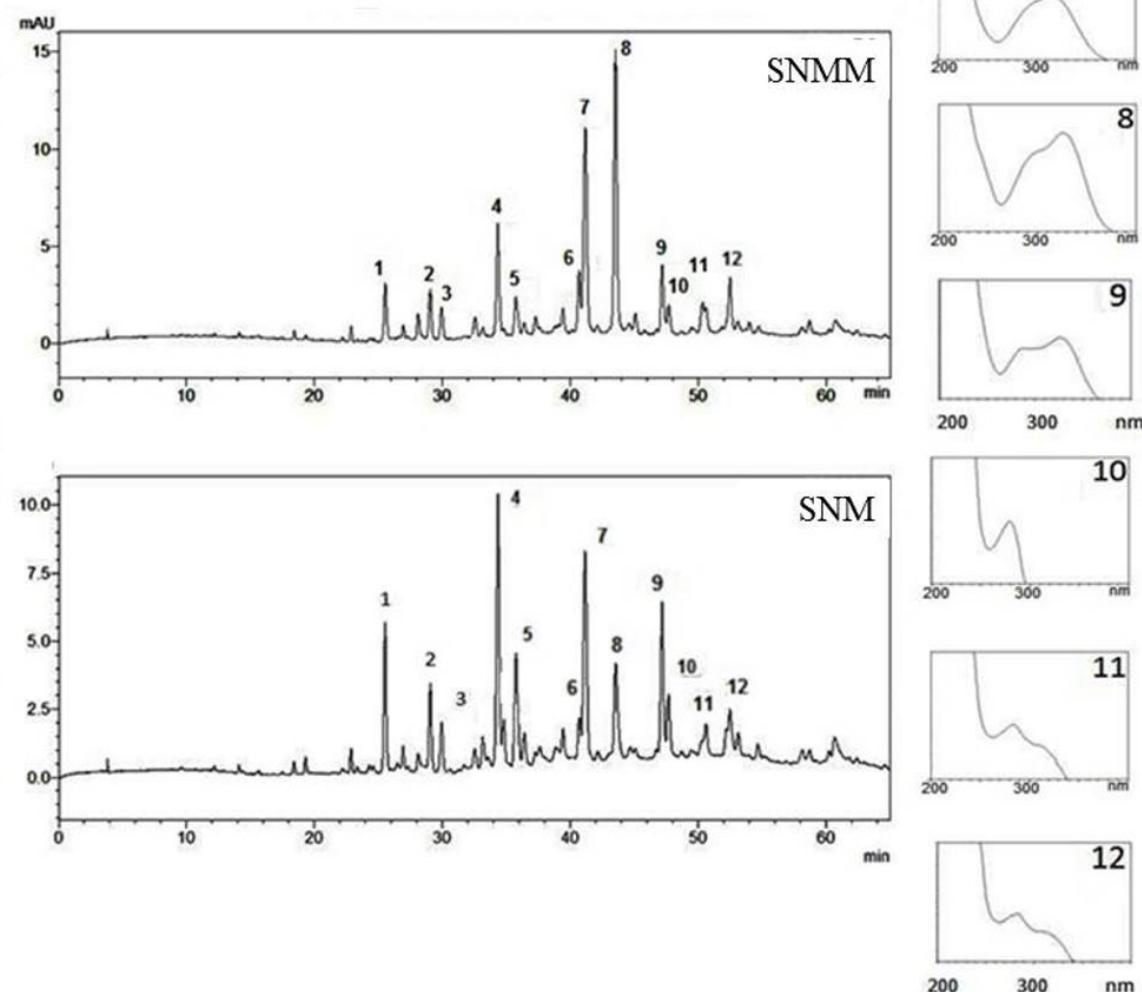

Figure 1. Chromatogram and ultraviolet (UV) spectra of methanolic Microgramma vacciniifolia extracts. SNMM (stem non-galled by micromoth), SNM (stem non-galled by midge). 
of micromoth-induced galls (MMIG), but differed from MIG and MIGP. Galling insects control phenolic biosynthesis in their hosts (Nyman and Julkunen-Titto, 2000) and
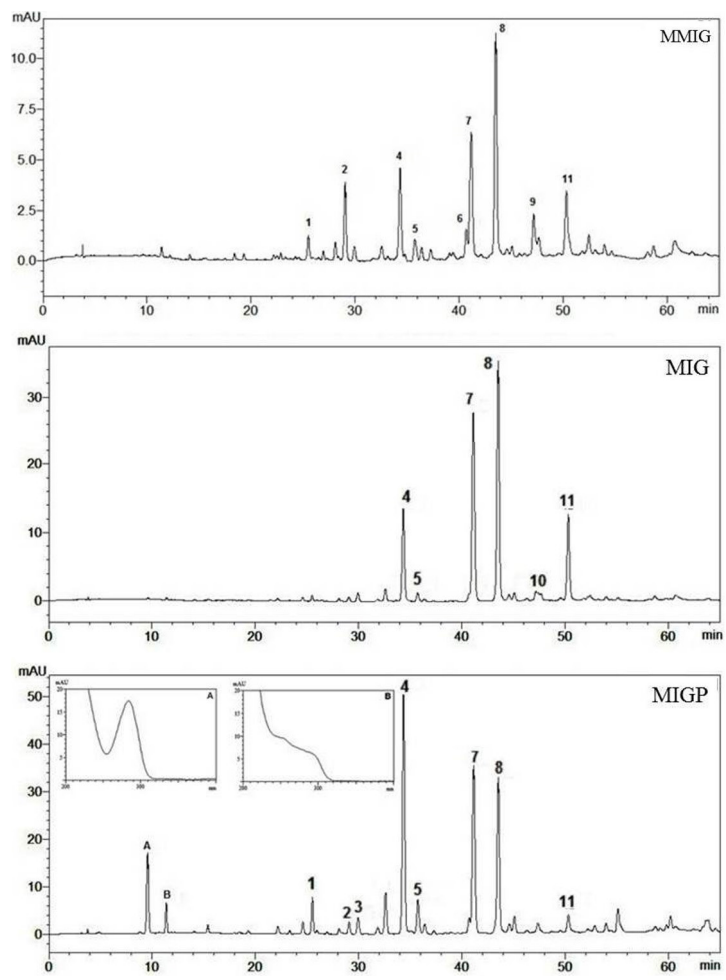

Figure 2. Chromatogram and ultraviolet (UV) spectra of methanolic Microgramma vacciniifolia extracts. MMIG (micromoth-induced galls), MIG (midge-induced galls), MIGP (midge-induced galls attacked by parasitoids). each inducer promotes species-specific alterations in the chemical composition of galled tissue (Hartley, 1998). Parasitoids (especially wasps) are the main natural enemies of gall-inducing insects, promoting a top-down effect on gall populations (Santos et al., 2012). The death of gallinducing insects ends their manipulation of host plant metabolism, which may explains the different phenolic profiles between MIG and MIGP.

Khattab and Khattab (2005) reported an accumulation of caffeic and coumaric acid in the galled leaves of Eucalyptus obliqua L'Hér. (Myrtaceae) when compared to non-galled leaves. Similary, Vereecke et al. (1997) found that caffeic acid was not detectable in non-galled tissues and appeared in significant concentrations in leafy galls of Nicotiana tabacum L. (Solanaceae). It is possible that caffeic and coumaric acid might accumulate as an expression of plant infection resistance (Matern and Kneusel 1988; Vereecke et al., 1997).

Cyanogenesis frequency differed in the non-galled tissue, galls and leaves of M. vacciniifolia. Santos et al. (2005) also reported the lower frequency of cyanogenesis in $M$. vacciniifolia stems than leaves, and its cyanogenic polymorphism, that is the variation of cyanogenesis profile between individuals and the organs of the same individual (Hegnauer, 1977; Oliveros-Bastidas and AlonsoAmelot, 2010).

All the stems near galls (SNM and SNMM) were non-cyanogenic. Research on plant species that exhibit cyanogenic polymorphism demonstrates that some herbivores prefer predating on non-cyanogenic individuals and avoid cyanogenic plants (Cooper-Driver and Swain, 1976; Bell, 2001). While all micromoth-induced galls were non-cyanogenic, some samples of midge-induce galls were cyanogenic. Cyanogenic potential depends on the concentration of cyanogenic precursors in each

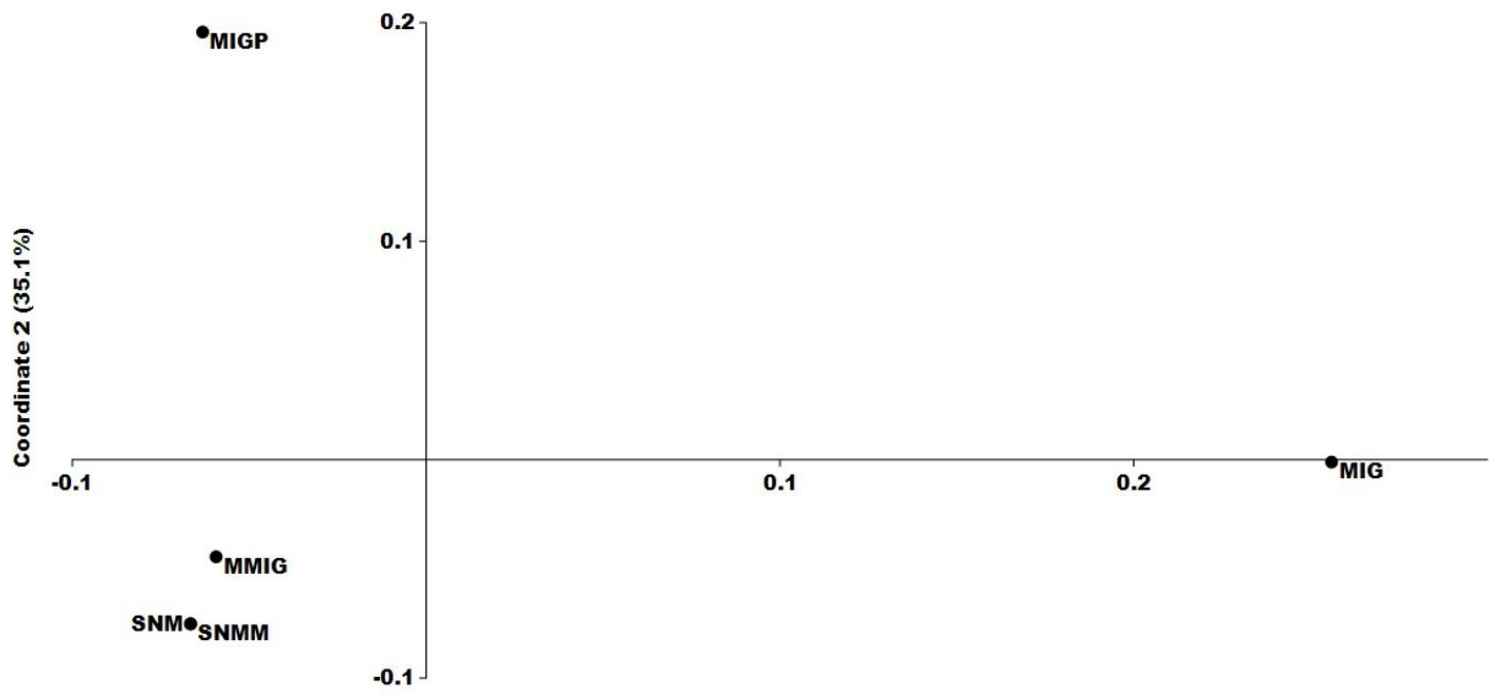

Coordinate $1(55.8 \%)$

Figure 3. PCoA (Principal Coordinates Analysis) ordination diagram for the presence and absence of the phenolic substances in galled and non-galled tissue of the Microgramma vacciniifolia. SNM (stem non-galled by midge), MIG (midge-induced galls), MIGP (midgeinduced galls attacked by parasitoids), SNMM (stem non-galled by micromoth), MMIG (micromoth-induced galls) 
Table 2. Cyanogenesis in Microgramma vacciniifolia. N (Total number of cyanogenic samples/total number of samples analyzed). $\mathrm{X}^{2}=27.02(\mathrm{DF}=7 \mathrm{P}=0.0003)$.

\begin{tabular}{|c|c|c|c|c|c|}
\hline & & \multicolumn{3}{|c|}{$\begin{array}{l}\text { Cyanogenic samples/total number of samples } \\
\text { analyzed }\end{array}$} & \multirow[t]{2}{*}{$\mathbf{N}$} \\
\hline & & Jun 2011 & Aug 2011 & Mar 2012 & \\
\hline \multirow{4}{*}{$\begin{array}{l}\text { Individuals with } \\
\text { midge-induced galls }\end{array}$} & Gall & $0 / 6$ & $3 / 9$ & $0 / 5$ & $3 / 20$ \\
\hline & Non-galled stem & $0 / 6$ & $0 / 9$ & $0 / 5$ & $0 / 20$ \\
\hline & Sterile leaf & $0 / 6$ & $5 / 9$ & $1 / 4$ & $6 / 19$ \\
\hline & Fertile leaf & $0 / 2$ & $0 / 9$ & $1 / 1$ & $1 / 12$ \\
\hline \multirow{4}{*}{$\begin{array}{l}\text { Individuals with } \\
\text { micromoth-induced } \\
\text { galls }\end{array}$} & Gall & $0 / 10$ & $0 / 11$ & $0 / 7$ & $0 / 28$ \\
\hline & Non-galled stem & $0 / 10$ & $0 / 11$ & $0 / 7$ & $0 / 28$ \\
\hline & Sterile leaf & $2 / 10$ & $3 / 11$ & $2 / 7$ & $7 / 28$ \\
\hline & Fertile leaf & $0 / 1$ & $0 / 11$ & $0 / 1$ & $0 / 13$ \\
\hline
\end{tabular}

plant tissue as well as $\beta$-glucosidase and $\alpha$-hydroxynitrile lyases activity (Zagrobelny et al., 2004; Kautz et al., 2014). Recent data show that plants express increased cyanogenic capacity (by induction $\beta$-glucosidases activity) in response to herbivore damage and jasmonic acid treatment (Kautz et al., 2014).

\section{Conclusion}

Our results indicate, at least for phenolic substances, that midge and micromoth gall-inducers promote speciesspecific alterations in the chemical composition of the $M$. vacciniifolia. In relation to cyanogenesis, stems non-galled and micromoth-induced galls were negative, whereas some midge-induced galls were positive, with greater frequency in leaves (fertile and sterile). The effects of this insect on cyanogenesis in the fern host remains to be tested.

\section{Acknowledgements}

The authors would like to thank CNPq (Conselho Nacional de Desenvolvimento Científico e Tecnológico Proc. 308045/2017-3), FAPERJ (Fundação Carlos Chagas Filho de Amparo à Pesquisa do Estado do Rio de Janeiro - Proc. E-26/203.236/2017) and PROCIENCIA (Scientific, Technical and Artistic Production Incentive Program) of UERJ (Universidade do Estado do Rio de Janeiro) for financial support.

\section{References}

BALICK, M.J., FURTH, D.G. and COOPER-DRIVER, G., 1978. Biochemical and evolutionary aspects of arthropod predation on ferns. Oecologia, vol. 35, no. 1, pp. 55-89. http://dx.doi.org/10.1007/ BF00345541. PMid:28309868.

BELL, E.A., 2001. Ecological biochemistry and its development. Phytochemistry, vol. 56, no. 3, pp. 223-227. http://dx.doi. org/10.1016/S0031-9422(00)00448-9. PMid:11243448.
BOEGE, K. and MARQUIS, R.J., 2005. Facing herbivory as you grow up: the ontogeny of resistance in plants. Trends in Ecology \&'Evolution, vol. 20, no. 8, pp. 441-448. http://dx.doi. org/10.1016/j.tree.2005.05.001. PMid:16701415.

BOHM, B.A. and TRYON, R.M., 1967. Phenolic compounds in ferns I. A survey of some ferns for cinnamic acid and benzoic acid derivatives. Canadian Journal of Botany, vol. 45, no. 5, pp. 585593. http://dx.doi.org/10.1139/b67-065.

BROWN, J.W., BAIXERAS, J., SOLORZANO-FILHO, J.A. and KRAUS, J.E., 2004. Description and life history of an unusual fern-feeding tortricid moth (Lepidoptera: Tortricidae) from Brazil. Annals of the Entomological Society of America, vol. 97, no. 5, pp. 865871. http://dx.doi.org/10.1603/0013-8746(2004)097[0865:DA LHOA]2.0.CO;2.

CAMPOS, M.G. and MARKHAM, K.R. 2007. Structure information from HPLC and on-line measured absorption spectra Flavone, Flavonols and Phenolic Acids. Coimbra: Imprensa da Universidade. http://dx.doi.org/10.14195/978-989-26-0480-0

COOPER-DRIVER, G.A. and SWAIN, T., 1976. Cyanogenic polymorphism in bracken in relation to herbivore predation. Nature, vol. 260, no. 5552, pp. 604. http://dx.doi.org/10.1038/260604a0.

FARIAS, R.P., SILVA, V.L., GONZATTI, F., LIMA, L.V., SCHMITT, J.L. and SANTOS, M.G., 2020. Galls on Brazilian ferns: new records and notes. Brazilian Journal of Biology = Revista Brasileira de Biologia, vol. 80, no. 1, pp. 199-205. http://dx.doi.org/10.1590/15196984.214565. PMid:31017244.

FARIAS, R.D., COSTA, L.E.N., OLIVEIRA, A.F.M., BARROS, I.C.L. and MEHLTRETER, K., 2019. Leaf defense syndromes in tropical ferns. Plant Ecology. http://dx.doi.org/10.1007/s11258-019-00983-4.

FRANCISCO, I.A. and PINOTTI, M.H.P., 2000. Cyanogenic Glycosides in Plants. Brazilian Archives of Biology and Technology, vol. 43, no. 5, pp. 487-492. http://dx.doi.org/10.1590/S151689132000000500007.

GUIGUET, A., DUBREUIL, G., HARRIS, M.O., APPEL, H.M., SCHULTZ, J.C., PEREIRA, M.H. and GIRON, D., 2016. Shared weapons of blood- and plant-feeding insects: surprising commonalities for manipulating hosts. Journal of Insect Physiology, vol. 84, pp. 4-21. http://dx.doi.org/10.1016/j.jinsphys.2015.12.006. PMid:26705897.

HARBORNE, J.B. 1984. Phytochemical methods. A guide to modern techniques of plant analysis. London: Chapmanand Hall, 288 p. 
HARBORNE, J.B., HARBORNE, J.B. and HARBORNE, J.B., 1999. Recent advances in chemical ecology. Natural Product Reports, vol. 16, no. 4, pp. 509-523. http://dx.doi.org/10.1039/a804621b. PMid: 10467740.

HARTLEY, S.E., 1998. The chemical composition of plant galls: are levels of nutrients and secondary compounds controlled by the gall-former? Oecologia, vol. 113, no. 4, pp. 492-501. http:// dx.doi.org/10.1007/s004420050401. PMid:28308028.

HEGNAUER, R., 1977. Cyanogenic compounds as systematic markers in tracheophyta. Plant Systematics and Evolution, vol. 1, pp. 191209. https://doi.org/10.1007/978-3-7091-7076-2_13.

ISAIAS, R.M.S., OLIVEIRA, D.C., CARNEIRO, R.G.S. and KRAUS, J.E. 2014. Developmental anatomy of galls in the neotropics: arthropods stimuli versus host plant constraints. In: G.W. Fernandes and J.C. Santos, eds. Neotropical insect galls. Netherlands: Springer, pp. 15-34. http://dx.doi.org/10.1007/978-94-017-8783-3_2.

KAUTZ, S., TRISEL, J.A. and BALLHORN, D.J., 2014. Jasmonic Acid Enhances Plant Cyanogenesis and Resistance to Herbivory in Lima Bean. Journal of Chemical Ecology, vol. 40, no. 11-12, pp. 1186-1196. http://dx.doi.org/10.1007/s10886-014-0524-z. PMid:25399357.

KHATTAB, H. and KHATTAB, I., 2005. Responses of Eucalypt Trees to the Insect Feeding (Gall-Forming Psyllid). International Journal of Agriculture and Biology, vol. 7, no. 6, pp. 979-984.

LEHN, C.R., ARANA, M.D., MÜLLER, G.A. and BIANCHINI, E., 2020. Occurrence of galls in Microgramma mortoniana (Polypodiopsida: Polypodiaceae) from a subtropical forest, Brazil. Lilloa, vol. 57, no. 1, pp. 72-80. http://dx.doi.org/10.30550/j.lil/2020.57.1/5.

MAIA, V.C. and SANTOS, M.G., 2011. A new genus and species of gall midge (Diptera, Cecidomyiidae) associated with Microgramma vacciniifolia (Langsd. \& Fisch.) Copel. (Polypodiaceae) from Brazil. Revista Brasileira de Entomologia, vol. 55, no. 1, pp. 4044. http://dx.doi.org/10.1590/S0085-56262011000100008.

MAIA, V.C. and SANTOS, M.G., 2015. Record of insects in two fern species of the genus Microgramma (Polypodiaceae) in the Atlantic Rain Forest, Rio de Janeiro state, Brazil. Brazil. Brazilian Journal of Biology = Revista Brasileira de Biologia, vol. 75, no. 4, suppl. 1, pp. S253-S254. http://dx.doi.org/10.1590/15196984.11114. PMid:26602333.

MANI, M.S. 1964. Ecology of plant galls. Netherlands: Springer. 434 p. http://dx.doi.org/10.1007/978-94-017-6230-4.

MATERN, Y. and KNEUSEL, R.E., 1988. Phenolic compounds in plant disease resistance. Phytoparasitica, vol. 16, no. 2, pp. 153-170. http://dx.doi.org/10.1007/BF02980469.

MELLO, M.O. and SILVA-FILHO, M.C., 2002. Plant-insect interactions: an evolutionary arms race between two distinct defense mechanisms. Brazilian Journal of Plant Physiology, vol. 14, no. 2, pp. 71-81. http://dx.doi.org/10.1590/S167704202002000200001.

NYMAN, T. and JULKUNEN-TITTO, R., 2000. Manipulation of the phenolic chemistry of willows by gall-inducing sawflies. Proceedings of the National Academy of Sciences of the United States of America, vol. 97, no. 24, pp. 13184-13187. http://dx.doi. org/10.1073/pnas.230294097. PMid:11078506.

OLIVEROS-BASTIDAS, A.J. and ALONSO-AMELOT, M.E., 2010. Cyanogenic polimorphysm in brackens, Pteridium arachnoideum and $P$. caudatum, from the Northern Andes. Quimica Nova, vol. 33, no. 7, pp. 1520-1524. http://dx.doi.org/10.1590/S010040422010000700018 .
PATRA, B., BERA, S. and MEHLTRETER, K., 2009. Structure, biochemistry and ecology of entomogenous galls in Selaginella Pal. Beauv. (Selaginellaceae) from India. Journal of Plant Interactions, vol. ••, pp. 1-8. http://dx.doi. org/10.1080/17429140903151257.

PERES, M.T.L.P., SIMIONATTO, E., HESS, S.C., BONANI, V.F.L., CANDIDO, A.C.S., CASTELLI, C., POPPI, N.R., HONDA, N.K., CARDOSO, C.A.L. and FACCENDA, O., 2009. Estudos químicos e biológicos de Microgramma vacciniifolia (Langsd. \& Fisch.) Copel. (Polypodiaceae). Quimica Nova, vol. 32, no. 4, pp. 897901. http://dx.doi.org/10.1590/S0100-40422009000400013.

RAMAN, A., 2007. Insect-induced plant galls of India: unresolved questions. Current Science, vol. 92, no. 6, pp. 748-757.

SANTOS, J.C., CARNEIRO, M.A.A. and FERNADES, G.W. 2012. Insetos galhadores neotropicais: diversidade e ecologia evolutiva dos herbívoros mais sofisticados da natureza. In: K. DEL-CLARO and H.M. TOREZAN-SILINGARDI, orgs. Ecologia das Interações PlantasAnimais. Rio de Janeiro: Technical Books Editora, pp.181-199.

SANTOS, M.G. and MAIA, V.C., 2018. A synopsis of fern galls in Brazil. Biota Neotropica, vol. 18, no. 3, 18. https://doi.org/10.1590/16760611-bn-2018-0513.

SANTOS, M.G., HANSON, P., MAIA, V.C. and MEHLTRETER, K., 2019. A review of galls on ferns and lycophytes. Environmental Entomology, vol. 48, no. 1, pp. 53-60. http://dx.doi.org/10.1093/ ee/nvy172. PMid:30561603.

SANTOS, M.G., CARVALHO, C.E.M., KELECOM, A., RIBEIRO, M.L.R.C., FREITAS, C.V.C., COSTA, L.M. and FERNANDES, L.V.G., 2005. Cianogênese em esporófitos de pteridófitas avaliada pelo teste do ácido pícrico. Acta Botanica Brasílica, vol. 19, no. 4, pp. 783788. http://dx.doi.org/10.1590/S0102-33062005000400014.

SCHREINER, I., NAFUS, D. and PIMENTEL, D., 1984. Effects of cyanogenesis in bracken fern (Pteridium aquilinum) on associated insects. Ecological Entomology, vol. 9, no. 1, pp. 69-79. http:// dx.doi.org/10.1111/j.1365-2311.1984.tb00699.x.

SOARES, G.L.G., ISAIAS, R.M.S., GONÇALVES, S.J.M.R. and CHRISTIANO, J.C.S., 2000. Alterações químicas induzidas por coccídeos galhadores (Coccoidea, Brachyscelidae) em folhas de Rollinia laurifolia Schdtl. (Annonaceae). Revista Brasileira de Zoociências, vol. 2, no. 1-2, pp. 103-116.

SUMMERS, C.B. and FELTON, G.W., 1994. Prooxidant effects of phenolic acids on the Generalist Herbivore Helicoverpa zea (Lepidoptera:Noctuidae): Potential mode of action for phenolic compounds in plantanti-herbivore chemistry. Insect Biochemistry and Molecular Biology, vol. 24, no. 9, pp. 943-953. http://dx.doi. org/10.1016/0965-1748(94)90023-X.

VETTER, J., 2000. Plant cyanogenic glycosides. Toxicon, vol. 38, no. 1, pp. 11-36. http://dx.doi.org/10.1016/S0041-0101(99)00128-2. PMid:10669009.

VEREECKE, D., MESSENS, E., KLARSKOV, K., DE BRUYN, A., VAN MONTAGU, M. and GOETHALS, K., 1997. Patterns of phenolic compounds in leafy galls of tobacco. Planta, vol. 201, no. 3 , pp. 342-348. http://dx.doi.org/10.1007/s004250050076. PMid:19343412.

ZAGROBELNY, M., BAK, S., RASMUSSEN, A.V., JøRGENSEN, B., NAUMANN, C.M. and LINDBERG MØLLER, B., 2004. Cyanogenic glucosides and plant-insect interactions. Phytochemistry, vol. 65, no. 3, pp. 293-306. http://dx.doi.org/10.1016/j. phytochem.2003.10.016. PMid:14751300. 